\title{
Analysis of the Effect of Sales Promotion and Advertising on Consumer Decisions at PT. Bank Negara Indonesia (Persero) Tbk Majene Branch
}

\author{
Erwin $^{1}$, Sri Utami Permata ${ }^{2}$ \\ \{erwin@unsulbar.ac.id, sriutamipermata@unsulbar.ac.id\}
}

Faculty of Economics, University of West Sulawesi, Jalan Prof. Dr. Baharuddin Lopa, S.H, Majene Regency, 91412, West Sulawesi ${ }^{1,2}$

\begin{abstract}
Various banking industry services are currently centered on the process, based on observations in terms of offering and delivery of messages carried out in attracting interest and as a medium of communication has not been maximized, because the delivery of various offers is more often applied through customer service. sales and advertising in influencing consumer decisions. This study uses primary data in the form of a questionnaire, and a Likert scale is used as the measurement design. In the data analysis process, using descriptive statistical analysis methods. The results show that the role of sales promotion and advertising has an influence on consumer decisions. Sales promotion with point-award indicators, meanwhile for bottom line media advertising such as calendars or displays, statistically achieves a fairly good score. Finally, the findings of this study imply that consumers still expect more sales promotion availability and information delivery to consumers.
\end{abstract}

Keywords: Sales Promotion, Advertising and Consumer Decisions.

\section{Introduction}

The industrial world has now significantly evolved, the rise and expansion of industry 4.0 is renewing the industry for the so-called digital transformation, which has brought enormous changes through the trend of automation and data exchange using the digitalization process. The fourth industrial revolution profoundly impact various sectors, including the economic sector in Indonesia and around the world. The sector which is dealing directly with the impact of this industrial revolution is the banking sector. Banks are financial institutions generally established with the authority to accept deposits from the publics, and lend money. The development of the technology has revolutionized all systems in the banking sector, including in digitizing assets such as providing special offers to customers and offering customization, etc., as important factors to not be left behind by the competitors.

Many services provided by the banking industry today, which are predominantly centered on the process down to the consumer, this is in line with [1] who stated that services are deeds, processes, and performances provided, reproduced, or made by a person or entity for another person or entity. With so many services, it certainly affects consumer decisions, where consumer decisions will return based on consumer behavior in responding to the messages 
provided, [2]. The banking industry carries out various ways of conveying messages with various communications to consumers, including sales promotions and advertising, where sales promotions are designed to produce immediate and specific actions [3], while advertising is any form of non-personal presentation of ideas by the use of mass media [4].

PT. Bank Negara Indonesia (Persero) - Tbk Majene Branch is one of the players in the banking industry in Indonesia, along with positive economic growth forming a conducive environment for the growth of the national banking business. In an effort to strengthen market positioning, particularly in the Business Banking sector. PT. Bank Negara Indonesia (Persero) - Tbk has carried out a series of business transformations that focus on customer-based businesses (customer centric), [5].

Through a Customer-Centric based approach and assisted by reliable and professional personnel in the marketing sector, PT. Bank Negara Indonesia (Persero) - Tbk is expected to be able to produce superior performance to provide high investment value for shareholders and to become the bank of choice for all financial needs of customers in all sectors with the best quality of service for customers. On the other hand, the goal of becoming a market leader in the business banking sector and the vision of becoming a superior, leading and foremost bank in service and performance can be achieved.

However, based on observation, several sales promotions and advertising implemented by PT. Bank Negara Indonesia (Persero) - Tbk Majene branch in attracting interest and as a communication media to deliver messages to consumers have not been optimal, because the provision to delivery of various offers is more often applied through customer service, so that messages that should be able to convey information to lots of consumers at once as a consideration in making decisions are not optimal. Consequently, consumers tend to have to find their own information regarding what they need.

In supporting PT. Bank Negara Indonesia (Persero) - Tbk, Majene branch aims to produce superior performance and to become the bank of choice for all financial needs of customers in all sectors with the best quality of service for customers. On the other hand, optimizing the existing sales promotion and advertising process at PT. Bank Negara Indonesia (Persero) - Tbk Majene branch needs to be done, so that the goal of becoming a market leader in the business banking sector can be achieved properly, this is in line with the results of a study conducted by [6], with the title of the effect of advertising and sales promotion on purchasing decisions, with the results of sales promotions implemented by PT. XL had a significant effect on purchasing decisions, which is then supported by the study by [7] with the title of Advertising, personal selling, sales promotion, and publicity on purchasing decisions at the Manado branch of Andi publishers. The results of this study indicated that partially advertising, personal selling, sales promotion, and publicity had a significant effect on purchasing decisions.

This study is conducted with the aim of examining the effects of sales promotion and advertising on the role of marketing media for PT. Bank Negara Indonesia (Persero) - Tbk Majene branch in influencing consumer decisions, so as to achieve goals along with the development of the banking business in Indonesia, particularly to become the bank of choice for all financial needs of customers in all sectors with the best quality service for customers and the market leader in the business banking sector. 


\section{Method}

The source of study data is the subject where data that is being used originates from. In data collection, this study used primary data in the form of questionnaires, and the Likert scale was used as the measurement design in this study. Because the exact number related to the study population that continues to move was still unknown, in determining the sample in this study, a quota sampling technique was used, where the researchers determined the number of study samples of 97 respondents and a factor analysis test had been carried out and obtained results $>0.60$ which means feasible to be continued according to [8]. In the data analysis process, this study used descriptive statistical analysis method, where the data in this study was analyzed by describing or describing the data that had been collected in the form of descriptions only, not explaining the mutual relationship, [9], by using SPSS Amos 23 for data analysis in the form of Structural Equation Model (SEM).

\section{Results}

\subsection{Meansurement model}

Confirmatory technique was used to assess the reliability, dimensions and validity of the multi-item scale. Each item of sales promotion was contained in three different indicators (PP1, PP2, PP3), advertising was included in three indicators as well (P1, P2, P3) and (KK1, $\mathrm{KK} 2, \mathrm{KK} 3$ ) were contained in consumer decision indicator. In this study, there was the suitability of the validity achievement with the acceptable confirmatory factor analysis (CFA) test, with a critical ratio $(\mathrm{CR})>1.96$ with a probability $(\mathrm{p})<0.05$ which can be seen in table 1.

Table 1. Regression Weights

\begin{tabular}{|c|c|c|c|c|c|c|c|}
\hline \multicolumn{3}{|c|}{ Indicator } & \multirow{2}{*}{$\begin{array}{c}\text { Estimate } \\
1.000\end{array}$} & \multirow[t]{2}{*}{ S.E. } & \multirow[t]{2}{*}{ C.R. } & \multirow[t]{2}{*}{$\mathbf{P}$} & \multirow[t]{2}{*}{ Label } \\
\hline PP3 & $\leftarrow$ & PP & & & & & \\
\hline PP2 & $\leftarrow$ & PP & 1.025 & .125 & 8.171 & $* * *$ & par_1 \\
\hline PP1 & $\leftarrow$ & PP & .725 & .110 & 6.574 & $* * *$ & par_2 \\
\hline $\mathrm{P} 3$ & $\leftarrow$ & $\mathrm{P}$ & 1.000 & & & & \\
\hline $\mathrm{P} 2$ & $\leftarrow$ & $P$ & .776 & .117 & 6.616 & $* * *$ & par_3 \\
\hline $\mathrm{P} 1$ & $\leftarrow$ & $\mathrm{P}$ & .698 & .128 & 5.471 & $* * *$ & par_4 \\
\hline KK1 & $\leftarrow$ & KK & 1.000 & & & & \\
\hline KK2 & $\leftarrow$ & KK & .904 & .103 & 8.788 & $* * *$ & par_5 \\
\hline KK3 & $\leftarrow$ & KK & 1.005 & .117 & 8.584 & $* * *$ & par_6 \\
\hline
\end{tabular}

In the Standardized Factor Loading column in Table 2, the validity results with the convergent test of all factor loading $>0.5$ and statistically significant without cross loading. In addition, the average variance extracted (AVE) and composite reliability (CR) values of each indicator variable > 0.5 and > 0.7. Bagozzi and Yi, 1988 in [10], who ensured the validity of the internal Meansurement model in this study. 
Table 2. Constructs and Meansurements Results

\begin{tabular}{|c|c|c|c|}
\hline Constructs and meansurements & $\begin{array}{c}\text { Standardized } \\
\text { factor Loading }\end{array}$ & $\mathbf{C R}$ & AVE \\
\hline Sales Promotion/PP (Shimp \& Andrews, 2013) & & 0.812 & 0.593 \\
\hline PP1 & 0.674 & & \\
\hline PP2 & 0.851 & & \\
\hline PP3 & 0.774 & & \\
\hline Advertising/P (J. Baker, 2003). & & 0.748 & 0.503 \\
\hline P1 & 0.585 & & \\
\hline $\mathrm{P} 2$ & 0.685 & & \\
\hline $\mathrm{P} 3$ & 0.835 & & \\
\hline Consumer Decisions/KK (Kotler \& Keller, 2016) & & 0.846 & 0.647 \\
\hline KK1 & 0.820 & & \\
\hline KK2 & 0.796 & & \\
\hline KK3 & 0.797 & & \\
\hline $\begin{array}{r}\text { Fit ina } \\
\text { Chi Square }=39.234(39.3641) ; \mathrm{p}=0.026 ; \mathrm{DF}= \\
\mathrm{RMSEA}=\end{array}$ & GFI $=0.915$ & 0.966 & 0.949 \\
\hline
\end{tabular}

\subsection{Structural model}

At this stage, the researchers examined the pathway that has been hypothesized in the proposed model. Previously, each variable contained three different indicators. Averagely, this study used three construct indicators. results.

On figure. 1 model was conceptualized and obtained an overall fit. Table 3 shows the

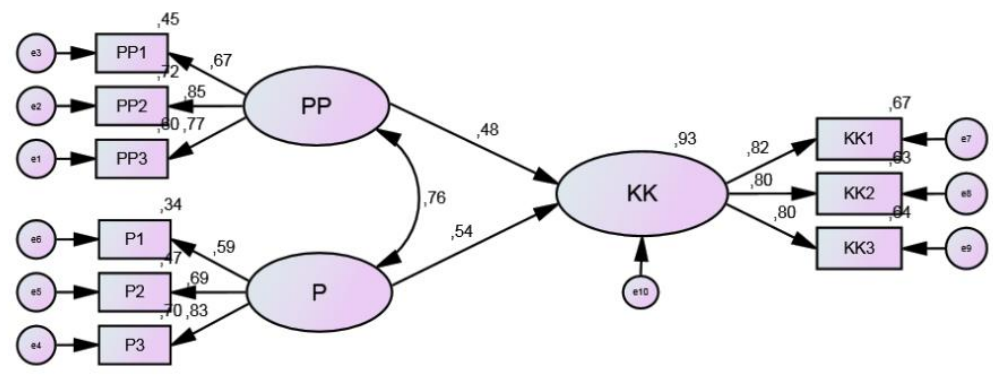

Figure 1. Full model

In connection with the study results, the sales promotion variable obtained a critical ratio $(\mathrm{CR})>1.96$ with a probability $(\mathrm{p})<0.05$. It can be said that it has a significant effect on consumer decisions. The strength of influence can be seen in the Standardized factor Loading column in Table 3.

Table 3. Hypothesis

\begin{tabular}{llccc}
\hline & Hypotheses & $\begin{array}{c}\text { Standardized } \\
\text { factor Loading }\end{array}$ & C.R. & P \\
\hline H1 & Sales Promotion $\rightarrow$ Consumer Decisions & 0.481 & 3.115 & 0.002 \\
H2 & Advertising $\rightarrow$ Consumer Decisions & 0.544 & 3.634 & $* * *$ \\
\hline
\end{tabular}


Fit indices

Chi Square= 39.234 (39.3641); $\mathrm{p}=0.026 ; \mathrm{DF}=24 ; \mathrm{GFI}=0.915 ; \mathrm{CFI}=0.966 ; \mathrm{TLI}=0.949$; RMSEA $=0.081$

$* * * \mathrm{p}<0.05$

Furthermore, the advertising variable also follows the sales promotion variable by obtaining a critical ratio $(\mathrm{CR})>1.96$ with a probability $(\mathrm{p})<0.05$. It can be said that it has a significant effect on consumer decisions. The strength of influence can be seen in the Standardized factor Loading column in Table 3 which is greater than the Standardized factor Loading value of the sales promotion variable.

\section{Discussion}

Marketing is defined as the process by which companies create value for customers and build strong customer relationships in order to capture value from customers in return [11]. In marketing itself, there are various concepts in conducting communications to consumers, such as sales promotions and advertising, which are part of the promotional mix. According to Kotler and Armstrong 2004 in [12] sales promotion is a short-term incentive to encourage the purchase or sale of a product/service. Then it should be noted that promotion involves incentives (allowances, discounts, sweepstakes, coupons, premiums, and so on) as a type of bonues or added benefit not as a substitute for the basic benefits that buyers usually get when purchasing a particular product or service [13], and according to [14], advertising is a form of paid communication that is mediated from an identifiable source, designed to persuade the recipient to take action, now or in the future. Referring to the definition of advertising as mentioned above, an indicator of advertising is the internet which functioned as new media and for traditional media such as posters, television, radio and cinema [15].

The purpose of this study was to examine the effect of sales promotions and advertising on consumer decisions which in theory according to Kotler and Keller, 2008 in [16], is a basic psychological process that plays an important role in how consumers actually make their buying decisions. The path by which consumers move through the decision-making stages depends on several factors, including level of engagement and level of search variation, [17] on the services products at PT. Bank Negara Indonesia Majene branch.

This study analyzed parts of sales promotion activities such as direct prizes, points and sweepstakes, as well as print, electronic and bottom line advertising. In addition, this study aimed to examine the role of sales promotion and advertising, which is based on the researchers' preliminary observations, personal selling through Customer Service is more dominant in marketing promotion in the banking industry.

The results of this study showed that the role of sales promotion and advertising has an influence on consumer decisions in the marketing process in the banking industry, particularly on the indicators of the availability of sales promotions in consumer decision variables which statistically reached a good enough value, so that it deserves to be maintained in subsequent marketing programs. In sales promotions, the use of promo points is still quite attractive to consumers compared to direct prizes and sweepstakes. For advertising, bottom line media such as exhibitions, calendars or displays statistically achieved a fairly good impact value compared to print and electronic media. 
Several implications arise from the results of this study, sales promotion and advertising are part of communication concepts that are important for companies in influencing consumer decisions. The more attractive the sales promotion that is carried out by the company, the higher consumer interest. In advertising, the selection of better media will also increase consumer interest and produce positive consumer decisions. In addition, when companies can choose well the form of sales promotion and advertising according to objectives, it will make the company's financial condition healthier for the expenses of sales promotion and advertising.

\section{Conclusion}

The findings in this study, which have previously been discussed in the results and discussion of the study, imply that consumers still expect more the availability of sales promotions and more intense advertising activities from the company. Furthermore, the high value of sales promotions through statistical point award indicators can be developed again through the calculation of points for each transaction as was done by one of the cellular telephone operators. In addition, cooperation with other companies also needs to be further developed in order to exchange points. If necessary, the number of points can be integrated with a number of points that are also applied by other companies, so as to attract more consumers. There are two options offered by the researchers, namely working with other companies to make it easier for exchanges, and working with other companies to combine points in collecting points by consumers, so that consumers can easily collect points.

As with some studies, there are limitations to this study. First, the development of creative ways of advertising, so that indicators appear that can support a positive direction. Second, the development of new ways of combining promos in order to maximize study results.

This study is a step towards understanding the role of sales promotion and advertising in consumer decision processes. The findings reported in this paper can contribute to the literature and offer some insight into how companies can manage marketing in the banking industry sector.

\section{References}

[1] Zeithaml, V. A.Bitner, M. J.and Gremler, D. D.:Services marketing: integrating customer focus across the firm, Seventh ed. Dubuque: McGraw-Hill Education, (2018).

[2] Kotler, P. and Keller, K. L.:Manajemen \{Pemasaran\}, 13th ed. Jakarta: Erlangga, (2008).

[3] Shinta, A.:Manajemen \{Pemasaran\}. Malang: UB Press, (2011).

[4] Putri, Tanama, B. R.:Marketing Management. Denpasar: Universitas Udayana, (2017).

[5] BNI: Https://Www.Bni.Co.Id, (2019). .

[6] Natalia, P. and Mulyana, M.: Pengaruh \{Periklaan\} Dan \{Promosi\} \{Penjualan\} \{Terhadap\} \{Keputusan\} \{Pembelian\}, JIMKES, vol. 02, (2014).

[7] Togas, N. M. N.Sepang, J. L.and Wenas, R. S.: Advertising, Personal Selling, Sales Promotion, And Publicity Against Purchasing Decisions At Andi Publisher Manado Branch, J. EMBA, vol. 02, p. 11, (2014). 
[8] Hair, J. F.Ed.:Multivariate data analysis, 7. ed., Pe. Harlow: Pearson, (2014).

[9] Radjab, E. and Jam'an, A.:Business Research Methodology. Makassar: Lembaga Perpustakaan dan Penerbitan Unismuh, (2017).

[10]Buil, I.de Chernatony, L.and Martínez, E.: Examining The Role Of Advertising And Sales Promotions In Brand Equity Creation, J. Bus. Res., vol. 66, no. 1, pp. 115-122, (2013), doi: 10.1016/j.jbusres.2011.07.030.

[11] Amstrong, G.Kotler, P.Trifts, V.Buchwitz, L. A.and Gaudet, D.:Marketing an Introduction, 6th ed. Canada: Pearson Canada Inc., (2017).

[12] Widyastuti, S.:Integrated Marketing Communication Management. Jakarta Selatan: Fakultas Ekonomi dan Bisnis Universitas Pancasila, (2017).

[13] Shimp, T. A. and Andrews, J. C.:Advertising, Promotion, and other aspects of Integrated Marketing Communications, 9th ed. United States: SouthWestern, (2013).

[14]Fill, C. and Turnbull, S.:Marketing Communications, 7th ed. United Kingdom: Pearson Education Limited, (2016).

[15] Baker, M. J.Ed.:The marketing book, 5th ed. Oxford; Boston: Butterworth-Heinemann, (2003).

[16] ErwinPermata, S. U.Tahawa, T. H. B.and Khaldun, R. I.: Analysis Of The Effect Of Sales Promotion And Advertising On Consumer Decisions In Choosing Services At PT. Astra International Tbk Daihatsu Makassar, Mala’bi STIE Yapman Majene, vol. 2, no. 1, pp. 1-8, (2019).

[17] Kotler, P. and Keller, K. L.:Marketing Management, 15th ed. England: Pearson Education Limited, (2016). 